\title{
LESSONS OF TRANSITION IN BULGARIAN SECURITY AND DEFENSE
}

\author{
Velizar SHALAMANOV
}

\section{Introduction}

A little over two years ago this journal published a translation of the famous article by Prof. Jeffrey Simon "Bulgaria and NATO: 7 lost years." Now, it can be stated that for less than three years the better part of the needed steps for the last ten years in the "information domain" were taken. The "magic formula" of democratic control of armed forces that provides transparency, cooperation and public support, as well as modern study methods, IT, new type of education, training and research is to prove that this transition is highly information intensive process. Any serious change simply needs preparation and a plan. Although changes are on different levels, in different areas, information and knowledge integrate all of them and management of change is again primarily seen as information/knowledge management.

The transition from armed forces, that used to be part of the Warsaw Pact military machine, designed and controlled by Moscow, to a new type of armed forces capable of responding adequately to the new reality, is a serious challenge to the postcommunist militaries. This new type of armed forces has to be governed by the principles of democratic civilian control and be part of a larger international security system. In addition to national defense, they have to perform a number of new tasks related to early warning, crisis prevention and management through military operations other than war (MOOTW) performed by combined joint task forces (CJTF).

There are different sets of criteria to highlight the transition of post-communists militaries developed in OSCE, NATO/PfP, based on the experience of NATO accession process and from the experience of different democratic countries that started some kind of defense diplomacy programs to support this transition period.

The OSCE criteria for effective civilian control of the armed forces were presented in 1995: clear, constitutionally defined distribution of responsibilities; parliamentarian 
oversight, approval of the budget and control of its implementation; civilian control of the military through a civilian minister and civilian staff capable of analyzing the budget, defense plans and programs, force structure and intelligence activity; armed forces that are an effective institution serving the society under the control of elected civilians and tasked with the protection of national security and participation in MOOTW.

The Partnership for Peace Program, launched in 1994, is instrumental in achieving desired status. The recently published transatlantic strategy of the United States ${ }^{2}$ provides a very simple definition of the PfP core objectives:

- Facilitate transparency in national defense planning and budgeting processes;

- Ensure democratic control of defense forces;

- Maintain capability and readiness to contribute to crisis response operations under the appropriate international mandate;

- Develop forces that are better able to operate with those of NATO members.

Similar to these are Secretary Perry's NATO accession criteria: democracy, market economy, good relations with neighbors, reform to build military capabilities, and democratic control of the armed forces. They are further developed in the Membership Action Plan (MAP) process on the basis of the accession experience of the first three former Warsaw Pact countries - the Czech Republic, Hungary and Poland - that joined NATO.

The transition of post-communists armed forces is a process, running parallel to the transition to democracy, market economy, and the rule of law in the respective countries.

In some aspects, the military transition is better to be considered in the larger context of the reform of the security sector, including reform of secret services, internal security and civil protection. On the one hand, this area is considered as a sector that is well organized and easy to control, but on the other hand, the establishment of democratic control is difficult for a number of reasons. Practically speaking, key elements of the process include political guidance and civilian control, introduction of modern management and information technologies (including PPBS-type of planning) and intensive education and training combined with a smart personnel policy. The attempts to assign the responsibility of transition to purely military organizations (for example the General Staff of the respective military force) were mostly unsuccessful. 
There are many lessons learned, that can be arranged in three levels:

- Redefinition of security and defense: from block confrontation to security and defense through cooperation and integration;

- Redefinition of the role of the military in the state - to provide security and defense and to support development of the country and its cooperation, the integration in the democratic, market oriented community of prosperous states;

- And on the basis of the previous two - to define the scope and depth of defense reform to support the national objectives.

Following are some thoughts in these three areas based mostly on the Bulgarian experience. We believe they reflect relatively common lessons and can be used as a basis for discussion. It is convenient, that this experience is well documented in a series of official security and defense related documents and, more importantly, in accounts of many studies performed by international teams, in itself a dimension of transparency. The study teams used modern information technologies, thus indicating the importance of IT for management of change. Study results and methodologies were often directly included in the education and training processes, which also proves how crucial all this is.

And yet, this process is a "two-way street" issue. There are some initiatives from Western countries, started as common to all militaries in transition, but later adjusted to each country on the basis of its particular experience, the latter being the most important factor for success. Therefore, my intention is to analyze not the Western, but our part of the transition efforts and stress on the fact that they are a national responsibility, based on national resources, including the human ones. Having this in mind, I would like to emphasize that without a great initial support it was impossible to get where we are now. Future progress will inevitably involve IT, education and training $(\mathrm{E} \& \mathrm{~T})$, research and development $(\mathrm{R} \& \mathrm{D})$, improved planning, intensive cooperation and integration processes.

\section{The role of security and defense in South East Europe (SEE) and the countries in transition}

During the period of block confrontation, Bulgarian security and defense were guaranteed by the Warsaw Pact. After its dissolution several different options were explored by Bulgarian society: from neutrality, through regional alliances and bilateral agreements, to NATO accession. Now it is clear that the ambiguity of that situation was contemptible for the military, but at the same time they were not prepared to offer professional military assessment of the different options (including resources and other external implications) in order to support the decision-making 
process. There was no proactive approach of the military that had been indoctrinated in the Soviet-style command and control system. At the same time, there was no civilian expertise and commitment to formulate a totally new concept and doctrine for the security and defense of the country.

Parallel to this, there was a process of transition to a system of civilian control. However, due to the lack of expertise in the civilian bodies, the lack of will in the political bodies and a certain level of encapsulation of militaries determined to keep the system as it was, the process was mutually blocked on a very high level. Lower levels were suppressed not to put at stake the imaginary stability.

Having no National Security Concept (National Security Strategy) and Military Doctrine (National Military Strategy) all reform attempts, covered by the Law on Defense and Armed Forces and the Manual for Career Development of Cadre Military, aimed at adapting to current situation. They rarely had any positive effect and caused a serious damage to the potential for change and development.

The first positive step was taken with the decision of the Government, dated 17 February 1997, to apply for NATO membership, followed by the first National Program for NATO Accession, adopted on March 17, 1997. It was further built on by the National Security Concept of the Republic of Bulgaria, approved by the Parliament in 1998 and estimated as real national achievement.

The lessons on this level include:

- Security and defense issues cannot be decided in secrecy by military professionals. These are "too serious problems to be addressed by generals alone";

- Security and defense are closely related to the vision on the overall development of the country. They are an issue of civilization choice, an issue of values;

- Security and defense are essential for the country, because they are a prerequisite for development (they are an investment in security and guarantee security of investments), but at the same time security and defense compete for the same limited resources with other state priorities. Balance, mutual support and synergy are crucial;

- Critical mass of experts - in society (NGOs, media, universities), in the ministries of defense, foreign affairs, and finance, in other government agencies and in Parliament, as well as the ones involved in close international cooperation - is needed to start the reform process;

- E\&T programs of Western countries and organizations were an important investment, but internal motivation and commitment of more and more 
Bulgarians was the decisive factor to overcome the inertia and the lasting sabotage of the former secret services.

All these lessons can be used to further outreach programs of introducing in more states national security concepts harmonized with those of the democratic community. This process is connected with deep and informative debate. Media, Internet, E\&T, $\mathrm{R} \& \mathrm{D}$ programs, joint studies are very important, and the supporting role of IT is indispensable.

\section{The role of the military in the democratic states}

The role of the military in a democratic society is extremely important and prestigious, but it is rather different from the one that existed during the totalitarian period. Having redefined security and defense on the political level, we found ourselves in a situation where there was a gap between new political framework and the existing military establishment. The role required by the state was difficult to be played by unreformed military, and the role that the unreformed military wanted to play was unacceptable for the state and society.

Within the framework of the above mentioned features of the transformation of postcommunist militaries, hard work was needed to define this new role, and to persuade the society and the military that this is of mutual interest. To persuade them that changes are difficult but need to be done for the sake of the country.

A lot of time was lost and, as a result, when realities started to require real military capabilities (not on paper), it became clear that there was no package of military capabilities, adequate to the resources and public support. Practically all plans were driven by the idea to keep large armed forces, even at the cost of no modernization, poor training levels and very limited crisis management capabilities. At the same time, the security environment was changing and the requirements to force structure, equipment, training, doctrines and, most of all, early warning and rapid reaction in unpredictable situations, became critical.

It was impossible to accomplish real reengineering of defense and armed forces with the armed forces' own resources. All proposals presented variations of the same structure, equipment, training and doctrines with unrealistic financial implications. There was resistance to initiate an in-depth strategic defense review with the assumption that there was no alternative to the General Staff in doing this; and if they were not the ones doing the review, the framework would be kept unchanged.

However, things started to change with the adoption of the National Security Concept, the direct involvement of the Prime Minister and the series of joint studies within the strategic defense review framework. The new security and defense 
structure was built on three pillars - cooperation, integration and optimal military capabilities, the first two actually being a catalyst to the strengthening of the third one.

The irreversibility of the change was also reinforced by the Military Doctrine of the Republic of Bulgaria. It was approved by Parliament in 1999 and proved adequate by the Kosovo crisis and the Washington Summit outcomes. The Military Doctrine and the Crisis Management Concept were the documents that framed the mature behavior of Bulgaria during the Kosovo crisis.

The main lessons on this level include:

- It is the responsibility of the civilians and society to define the role of the military in the national security system;

- Any kind of defense reform without political guidance and civilian control is simply a waste of time, resources and confidence in the transition efforts;

- Civilian authorities cannot fulfill their responsibilities without a strong analytical support, control of the military education and personnel policy, as well as without a system for strengthening the public support;

- Two-level integration (between civilians and military, and between national and foreign experts) is possible only after developing a certain capacity in the differentiation phase (a separate capacity for civilian and military, for national and foreign experts). Only after that, and on the basis of a clear statement of work (SOW), high level approval and under tight political control joint teams can start working effectively;

- A clear system of measuring the military activity and real use of military capabilities - exercises, crisis management, MOOTW, etc., is essential to define and prove the new role of the military;

- Cooperation and integration processes, force structure, equipment, doctrines, training, education and personnel policy embedded within the PPBS are powerful tools to redefine the role of the military;

- Policy guidance and control is a responsibility of the civilians, the implementation - of the military, and the kernel - planning and programming - is a joint activity.

All these lessons need IT for effective implementation. At the same time, successful accomplishment of the above changes provides environment for effective implementation of modern IT. 


\section{Milestones of the transition process}

This is the third level - the level of practical implementation of the above mentioned principles and documents which proves how crucial the democratic control of armed forces is.

Following is only a short description of the transition phases of the Bulgarian experience:

\section{0-1996:}

Waiting for political guidance, full dominance of the General Staff, preservation of old structures, erroneous procurement policy, exhausting of reserves, sporadic bilateral cooperation, formal participation in international organizations:

- New Law on Defense and Armed Forces, 1995; Amended in 1996.

\section{7-1998:}

Clear political will, shaping the political framework, lack of competence of the civilian administration of the MoD, more open bilateral and regional cooperation, vitalization in the area of integration on political level:

- Declaration of Determination to join NATO, February 1997;

- Creation of Inter-ministerial Committee for NATO integration, February 1997 ;

- $\quad$ First National NATO Accession Program, March 1997;

- "Reform Plan 2010," 1998;

- $\quad$ First National Security Concept, April 1998;

- Amendments to the Law on Defense and Armed Forces, 1997, 1998.

\section{9-current:}

Direct involvement in the defense reform of the Government and the Prime Minister through the Security Council; building internal capacity for strategic defense review and defense planning, increased integration of the Ministry of Defense and the General Staff, development of realistic reform and integration plans, proactive regional and integration policy:

- Joint US-Bulgarian Defense Reform Study, 1999;

- Crisis Management Concept, March 1999;

- First Military Doctrine of the Republic of Bulgaria, April 1999;

- Defense Reform "Plan 2004,” October 1999; 
- Bulgarian Membership Action Plan, October 1999;

- C4, Air Defense, Civil-Military Relations /Integrated MoD/ studies, 19992000 ;

- "Organic Law" of the MoD, defining organizational structure and functions of the administration, 1999;

- New Manual on Career Development of Cadre Military;

- Amendments to the Law on Defense and Armed Forces, 2000;

- Mid-term departmental plan organized in 21 comprehensive programs, 1999, 2000;

- First annual reports on National Security and on Status of Defense and Armed Forces, 2000;

- Full harmonization of the national and NATO defense planning, 2001;

- First draft version of White Paper on Defense and Armed Forces, January 2001.

A short analysis of the bullets (even only of their number, not content) can give a clear idea for the importance of democratic control of armed forces and mature civilmilitary relations. An in-depth content analysis is a serious task that can lead us to extremely important lessons about the national defense policy and defense diplomacy, but this is a topic for another study.

Following one full year of implementation of the above documents, plans and programs, there are many lessons learned, but it is important to stress that they are just to prove the importance of the principles listed in the introduction.

These lessons include:

- Crucial role of political guidance, will and control;

- Requirement to delegate decision making authority and control;

- Key role of programming in linking results to resources within an adequate time frame;

- Essential role of the new information technologies - communications, computers and decision support tools, as well as R\&D in all defense reform related areas;

- Critical role of education, training and personnel policy - to select and motivate the right people;

- The importance of the ownership of the processes by right level people;

- The decisive role of progress reports to control the process and gain support and motivation. 
To a great extent these lessons were taken into account and incorporated in the Reform Plan 2004 and the Membership Action Plan of the Republic of Bulgaria approved by the Government in 1999; the Bulgarian system for planning, programming and budgeting; the reform initiated in the field of E\&T and R\&D; the establishment of "Chief Information Officer" and the elaboration of the respective manual for life cycle support of $\mathrm{C} 4$ systems in the MoD. ${ }^{3}$

This is a "live" process and the permanent improvement and management of the change is something that needs continuity and commitment. Many processes underway are result of compromises that only people deeply involved are aware of. Therefore, it is extremely important to keep teams together. The old thinking that everything can be put on paper and after that implemented by other people without permanent improvement of the "fathers" is dangerous for the fragile transition. As the military say, "Plans are nothing, planning is everything", so keep planning and implementing - management of change by a strong team, supported by effective information systems and solid political and public support.

\section{Conclusion}

The main lesson is that transition will never come to an end but there will always be a constant development and progress. The implementation of Plan 2004 and the MAP, the accession to NATO and the EU are only milestones of a long journey to better security through cooperation and integration that will provide opportunities for prosperity of more people as well. In order to support this process we give priority to the improvement of the system for democratic control of armed forces and the security sector as a whole. This will introduce transparency, accountability, effectiveness and efficiency through our PPBS, strengthening the implementation of modern management and information technologies and excellence in our E\&T / R\&D system.

Gaining political and public support for the transition is crucial. After four years of serious efforts we are really close to understanding our own lessons. Together with our people, this is the most valuable asset for the most serious part of the Bulgarian transition - receiving an invitation to join NATO and finalizing the process of building the first military blocks to contribute within the Alliance New Strategic Concept.

The success story of Bulgaria has proved that military reform efforts have a great potential when they are proactive and linked to the overall integration processes throughout Europe.

It is important to stress that reform is like love - it's a journey, not a destination... 
To achieve your destination, though, you need appropriate speed, determination and clear perspective as to where your heart and mind drive you. And if you need a formula for military reform, go back to Benjamin Disraelie's definition: "The secret of success is constancy of purpose."

In the past it was stated that the direction was important, not the speed. Now, in the information age, in the age of change, it is not only the direction and the speed that are the most important; it is the acceleration. And, of course, the purpose has to be the same - more security and prosperity for more people. This purpose is essential for the transition of post-communist militaries and it is the responsibility of elected civilians (consulted by military and civilian professionals) to guide the execution by military professionals and to provide public support for the process.

Transition is impossible in isolation. Success in security and defense reform requires synergy of effort in international cooperation and integration endeavors, transparency through systemic democratic control of armed forces, effective implementation of new IT, developing the foundation for the future through education and training, $\mathrm{R} \& \mathrm{D}$, and, finally, constantly measuring progress both in formal and informal ways, as well as through participation in real-world crisis management operations.

Acknowledgment. The most intensive period of the changes started at the end of 1998. Genuine defense reform was possible because of the commitment, intellectual effort, and hard work of many young, motivated and well-educated people, who became part of the defense policy and planning sector of the Ministry of Defense. But it is not possible to name everyone who spent long work hours and many weekends away from their families. Invaluable was the assistance of experienced specialists of the Ministry of Defense and the General Staff, who decided to open a new page in their endeavors. Many people from outside the Ministry of Defense contributed and, of course, the support of Government, Parliament and society was crucial. This is probably the first time when Bulgarian society was so actively involved in planning and implementing security and defense reform. The role of the joint studies and foreign consultants is difficult to measure, but their significance is beyond doubt.

\section{References:}

1. Jeffrey Simon "Bulgaria and NATO: 7 lost years," Strategic Forum, No. 142. Published in Bulgarian in Information \& Security. An International Journal 1, 2 (Fall, Winter 1998), 93-104. 
2. Strengthening Transatlantic Security: A U.S. Strategy for the $21^{\text {st }}$ Century (Washington, DC: Department of Defense, December 2000).

3. Described in detail in articles in this volume.

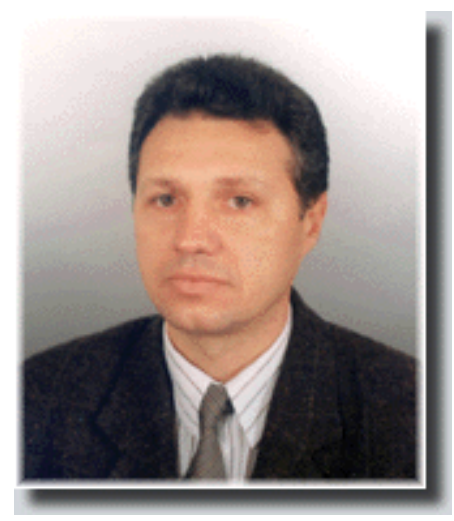

Dr. VELIZAR SHALAMANOV is Deputy Minister of Defense for Defense Policy and Planning since November 1998. He holds the title of Associate Professor on automated information processing systems (Computer Science and Operations Research) and has with more than 120 publications in areas of CIS architecture and development, IW, decision support, national and regional security policy, military art, defense reengineering, defense planning, democratic control of armed forces and security sector, defense $R \& D$, education and training. Dr. Shalamanov is member and co-founder of AFCEA-Sofia Chapter, member of Council of Geneva Center for Democratic Control of Armed Forces, member of Bulgarian Coordinating Council on the Problems of Information Society and Bulgarian Interagency Committee for NATO Integration, as well as of other national and international institutions. Email: shalamav@md.government.bg; shalamav@bg.pims.org. 